\title{
The Antidiabetic Activity of Nigella sativa and Propolis on Streptozotocin-Induced Diabetes and Diabetic Nephropathy in Male Rats
}

\author{
Haddad A. El Rabey, ${ }^{1,2}$ Madeha N. Al-Seeni, ${ }^{1}$ and Amal S. Bakhashwain ${ }^{1}$ \\ ${ }^{1}$ Biochemistry Department, Faculty of Science, King Abdulaziz University, Jeddah, Saudi Arabia \\ ${ }^{2}$ Bioinformatics Department, Genetic Engineering and Biotechnology Institute, University of Sadat City, Sadat City, Monufia, Egypt \\ Correspondence should be addressed to Haddad A. El Rabey; elrabey@hotmail.com
}

Received 3 July 2016; Accepted 19 January 2017; Published 16 February 2017

Academic Editor: Andrzej K. Kuropatnicki

Copyright (C) 2017 Haddad A. El Rabey et al. This is an open access article distributed under the Creative Commons Attribution License, which permits unrestricted use, distribution, and reproduction in any medium, provided the original work is properly cited.

\begin{abstract}
This study was conducted to compare the ameliorative effect of Nigella sativa and propolis methanol extract on streptozotocininduced diabetic male rats and treating diabetic nephropathy. Forty male Albino rats were divided into four groups; the first group was the negative control fed standard diet. The other 30 rats were injected with streptozotocin to induce diabetes by a single intravenous injection and then divided equally into three groups; the second group was the positive diabetic control; the third and the fourth groups were treated orally with $20 \% \mathrm{w} / \mathrm{w}$ Nigella sativa seeds methanol extract and propolis methanol extract $(20 \% \mathrm{w} / \mathrm{w})$, respectively. The rats of the second group showed increased glucose levels and lipid peroxide accompanied with reduction in superoxide dismutase, catalase, and glutathione-S-transferase enzyme activities compared with the negative control. Carboxymethyl lysine, interleukin-6, and immunoglobulins were also increased as a result of diabetes. Kidney function parameters were also elevated, while potassium and sodium levels were decreased. Moreover, tissues of kidney and pancreas showed severe histopathological changes. Treating the diabetic rats with Nigella sativa and propolis methanol extract in the third and fourth groups, respectively, ameliorated all altered biochemical and pathological examinations approaching the negative control. Propolis was more effective than Nigella sativa.
\end{abstract}

\section{Introduction}

Diabetes mellitus (DM) is a heterogeneous disease, characterized by chronic hyperglycaemia caused by defects in insulin secretion, insulin action, or both, resulting in impaired function in carbohydrate, lipid, and protein metabolism [1]. Moreover, hyperglycemia is considered a major factor responsible for the intense oxidative stress in diabetes through the overproduction of reactive oxygen species $[2,3]$, which results in an imbalance between excess formation of reactive oxygen species (ROS) and ability of a biological system to readily detoxify the reactive intermediates or to repair the resulting damage. ROS interact with the free amino and sulfhydryl groups of proteins forming Amadori products which further modified to form advanced glycation end products (AGEs) especially carboxymethyl lysine (CML) [4], contributing to development of diabetic complication [5]. The formed AGEs bind to their receptors (AGE-receptors) on the cell membrane resulting in the activation of the nuclear factor kappa B (NF- $\kappa \mathrm{B})$, which plays an important role in inducing genes involved in the control of the immune system as well as in the response to injury and infection such as IL-6 and immunoglobulins [4].

Effective control of hyperglycemia in diabetic patients is critical for reducing the risk of micro- and macrovascular complications [6]. Natural sources play an important role in the management of diabetes mellitus, especially in developing countries, delaying the development of diabetic complications and correcting the metabolic abnormalities [7]. Nigella sativa (black seed) and propolis are among the natural sources reported to have beneficial effects in the treatment of many diseases [8]. N. sativa has many beneficiary effects such 
as an anticancer, anti-inflammatory, cardiovascular, renal, immunomodulatory, and antidiabetic effects as well as many other effects like antiasthmatic, antimicrobial, antiparasitic, and antihypertensive effects. Moreover, the seeds of $N$. sativa are widely used in the treatment of various diseases like bronchitis, diarrhea, rheumatism, and skin disorders [9]. The efficacy of $N$. sativa is related to numerous active components which have been isolated from seeds and its oil including thymoquinone, thymohydroquinone, dithymoquinone, thymol, carvacrol, nigellimine-N-oxide, nigellicine, nigellidine, and alpha-hederin [10], as well as flavonoids [11].

Propolis is a natural resinous mixture produced by honeybees from substances collected from parts of plants, buds, and exudates which is widely used in folk medicine in various parts of the world for several applications as anti-inflammatory [12], antioxidative [13], antiproliferative [14], antidiabetic [15], and antimicrobial [16] agent. More than three hundred organic compounds of different groups, mainly phenolic, such as flavonoids and phenolic acids, have been identified in propolis [17]. Furthermore, caffeic acid of propolis is known to play an important role in reducing the inflammatory response and also aids the immune system by promoting phagocytic activities and stimulates cellular immunity [18].

This study aimed to evaluate the protective effect of Nigella sativa and propolis methanol extracts on streptozotocin-induced diabetes and treating diabetic nephropathy in male rats.

\section{Materials and Methods}

N. sativa and propolis were purchased from a local herbal medicine shop in Jeddah, Saudi Arabia.

2.1. Diet. The animal diet was obtained from a grain mill in Jeddah, Saudi Arabia. A $100 \mathrm{~g}$ of the conventional animal basal diet consists of $4 \mathrm{~g}$ corn oil (4\% fat), $4 \mathrm{~g}$ minerals ( $4 \%$ minerals), $12 \%$ protein (17.14 $\mathrm{g}$ of $70 \%$ casein), $0.2 \mathrm{~g}$ choline chloride $(0.2 \%), 0.3 \mathrm{~g}$ methionine $(0.3 \%), 4 \mathrm{~g}$ cellulose $(4 \%$ fiber), $1 \mathrm{~g}$ vitamin mixture ( $1 \%$ vitamin), and $69.36 \mathrm{~g}$ of corn starch $(69.36 \%)$. The diet was stored in a dark dry place.

Total carotenoids were extracted with acetone-hexane mixture and determined with a spectrophotometer at wavelength of $440 \mathrm{~nm}$ as described by Dubois et al. [19].

2.2. Preparation of Methanol Extract. Methanol extracts were prepared by soaking $200 \mathrm{~g}$ of dry N. sativa seeds or propolis in 1 liter of $90 \%$ methyl alcohol under shaking for 5 days and then kept in a refrigerator. Methanol was evaporated using a rotatory evaporator apparatus. $20 \mathrm{~g}$ of the semisolid extract of both $N$. sativa and propolis was suspended in $100 \mathrm{~mL}$ distilled water with $2 \mathrm{~mL}$ of tween 80 (suspending agent) to prepare a $20 \%$ solution [20].

2.3. Phytochemical Analysis. The total flavonoid content of each extract was determined by a colorimetric method as described by Zhishen et al. [21]. $0.5 \mathrm{~mL}$ of each sample was mixed with $2 \mathrm{~mL}$ of distilled water, and then $0.15 \mathrm{~mL}$ of $\mathrm{NaNO}_{2}$ solution (15\%) was added. $0.15 \mathrm{~mL}$ of aluminum chloride $\left(\mathrm{AlCl}_{3}\right)$ solution $(10 \%)$ was added after $5 \mathrm{~m}$ and allowed to stand for 6 minutes, and then $2 \mathrm{~mL}$ of $4 \% \mathrm{NaOH}$ solution was added to the mixture. Water was added to bring the final volume to $5 \mathrm{~mL}$ immediately. The mixture was thoroughly mixed and allowed to stand for another 15 minutes. The absorbance of the mixture was measured at $510 \mathrm{~nm}$.

2.4. Animals and Housing Conditions. Forty male Albino rats (180-200 g) were obtained from the animal experimental unit of King Fahd Center for Medical Research, King Abdulaziz University. The animal experiments were carried out according to protocols approved by the Institutional Animal House of the University of King Abdulaziz at Jeddah, Saudi Arabia. Rats were kept for two weeks before the start of the experiment for acclimatization. The animals were then housed 5/cage and received normal basal diet and tap water ad libitum at a room temperature of about $28 \pm 2^{\circ} \mathrm{C}$, a room humidity of $60 \pm 5 \%$, and a $12 \mathrm{~h}$ light and $12 \mathrm{~h}$ dark cycle.

2.5. Experiment Design. The animals were divided into 4 groups, each consisting of 10 rats. The first group (G1) received only a single tail vein injection of $0.1 \mathrm{~mol} / \mathrm{L}$ citrate buffer. The other 30 rats were subjected to fasting for $12 \mathrm{~h}$ and were then intravenously injected with freshly prepared streptozotocin $(65 \mathrm{mg} / \mathrm{kg}$ body weight $)$ in a $0.1 \mathrm{~mol} / \mathrm{L}$ citrate buffer ( $\mathrm{pH} 4.5$ ). After 5 days of injection, rats with blood glucose higher than $200 \mathrm{mg} / \mathrm{dL}$ in the fasting state were considered diabetic. The other rats with blood glucose lower than $200 \mathrm{mg} / \mathrm{dL}$ were discarded from the study. The experiments were started one week after STZ injection. The 30 diabetic rats were then randomly divided into 3 groups: the second group (G2) received only STZ and fed normal basal diet. The third group (G3) was treated with $(20 \%$ w/w) Nigella sativa seeds methanol extract using stomach tube. The fourth group (G4) was treated with $(20 \% \mathrm{w} / \mathrm{w})$ propolis methanol extract using stomach tube. Treatment was continued for 4 weeks.

2.6. Urine Sample. Urine samples were collected before induction of diabetes and one day before the end of the experiment by placing the rats in individual metabolic cages for $24 \mathrm{~h}$. Albumin and creatinine levels were determined in the urine samples.

2.7. Blood Sampling and Analysis. At the end of the experiment, rats were fasted 14-16 hours after their last feeding, and then blood samples were collected from the heart of each rat under anesthesia with diethyl ether. Blood samples were centrifuged at $2,000 \mathrm{~g}$ for 10 minutes at $4^{\circ} \mathrm{C}$ and serum was removed and stored at $-80^{\circ} \mathrm{C}$ until analysis.

2.8. Dissection. The abdomen of ether anaesthetic rats was dissected and the kidneys and pancreas were dissected out. One kidney was kept in ice for kidney homogenate preparation and the other kidney and the pancreas were saved in saline buffer $(0.9 \% \mathrm{NaCl})$ for histopathological investigations.

2.9. Kidney Tissue Homogenate. Kidney tissues were cut into small pieces, washed with phosphate-buffered saline, 
and then ground in a homogenization buffer consisting of $0.05 \mathrm{M}$ Tris- $\mathrm{HCl} \mathrm{pH} \mathrm{7.9,25 \%} \mathrm{glycerol,} 0.1 \mathrm{Mm}$ EDTA, and $0.32 \mathrm{M}\left(\mathrm{NH}_{4}\right)_{2} \mathrm{SO}_{4}$ containing a protease inhibitor tablet (Roche, Germany). The lysates were homogenized on ice using a Polytron homogenizer and then sonicated in an ice bath to prevent overheating for 15 seconds followed by 5minute centrifugation at $12000 \mathrm{rpm}$ and $4^{\circ} \mathrm{C}$. The supernatant was aliquoted and stored at $-80^{\circ} \mathrm{C}$ until use. The kidney homogenate was used for estimating the activity of antioxidant enzymes and lipid peroxidation as well as level of IL-6.

2.10. Determination of Fasting Blood Sugar (FBS). Fasting blood sugar was estimated using glucose kit from HUMAN (Germany) according to Barham and Trinder [22].

2.11. Determination of Lipid Peroxide. Lipid peroxide was estimated by determination of malondialdehyde (MDA) in the serum and in the kidney tissue homogenate according to the method described by Ohkawa et al. [23] using commercially available kits from Biodiagnostic Chemical Company (Egypt).

2.12. Estimation of Antioxidant Enzymes Activity. Superoxide dismutase (SOD), catalase (CAT), and glutathione-Stransferase (GST) activities were estimated in the serum and in the kidney tissue homogenate according to the method described by Nishikimi et al. [24], Aebi [25], and Habig et al. [26], respectively, using commercially available kits from Biodiagnostic Chemical Company (Egypt).

2.13. Determination of Interleukin-6 (IL-6). IL-6 levels in serum and kidney tissue homogenate were determined using Rat IL-6 Immunoassay kit from R\&D Systems Inc. (USA) according to the method of Hibi et al. [27].

2.14. Determination of Immunoglobulins (Ig). Immunoglobulins ( $\operatorname{IgA}$, $\operatorname{IgM}$, and $\operatorname{IgG}$ ) were estimated in the serum according to Fahey and Mckelvey [28] and Berne [29] using commercially available kits from GenWay Biotech (USA).

2.15. Determination of Carboxymethyl Lysine (CML). Carboxymethyl lysine (CML) was estimated in the serum using commercially available kit according to the method described by Seigel et al. [30] from MyBioSource (Canada). This kit employs Double Antibody Sandwich Technique.

2.16. Determination of Kidney Functions. Urea, creatinine, and uric acid were estimated in the serum according to the method described by Fawcett and Scott [31], Bartels et al. [32], and Fossati et al. [33], respectively, using enzymatic colorimetric kit from HUMAN (Germany), while albumin was estimated in urine by ELISA according to Sayed [34] using a Nephrat II Albumin Kit (USA) and the concentration of creatinine urine samples was determined by the commercial HUMAN kit (Germany) according to the method of Bartels et al. [32].

2.17. Determination of Electrolytes. Sodium $\left(\mathrm{Na}^{+}\right)$and potassium $\left(\mathrm{K}^{+}\right)$were estimated in the serum according to Trinder
[35] and Terri and Sesin [36], respectively, using HUMAN kits (Germany).

\subsection{Physiological Evaluations}

(i) Food intake and water consumption were calculated daily.

(ii) Food efficiency ratio (FER), food efficiency ratio percentage (FER\%), body weight gain (BWG), and body weight gain percentage (BWG\%) were calculated according to the method of Davies and Morris [37].

2.19. Histopathological Examination. Kidney and pancreas tissues were kept in saline after animal sacrifice, fixed in $10 \%$ formalin, processed routinely, and then embedded in paraffin. $5 \mu \mathrm{m}$ thick sections were prepared and stained with hematoxylin and eosin ( $\mathrm{H} \& \mathrm{E})$ dye for microscopic investigation (Drury et al. [38]). The stained sections were examined and photographed using Olympus light microscope equipped with a digital camera.

2.20. Statistical Analysis. The scored values were analyzed using SPSS program to calculate $t$-test and the mean \pm SD and then analyzed using one-way analysis of variance (ANOVA, $P<0.05)$ using a protected least significant difference (LSD) test of SAS [39].

\section{Results}

3.1. Phytochemical Analysis. The spectrophotometric evaluation of the antioxidants (flavonoids and carotenoids) showed that $N$. sativa seed contains $993.6 \mathrm{mg} / 100 \mathrm{~g}$ dry weight flavonoids and $80.6 \mathrm{mg} / 100 \mathrm{~g}$ dry weight carotenoids, whereas propolis contains $4630 \mathrm{mg} / 100 \mathrm{~g}$ dry weight flavonoids and $1.92 \mathrm{mg} / 100 \mathrm{~g}$ dry weight carotenoids.

3.2. Fasting Blood Sugar (FBS). Effect of treating STZinduced diabetic rats with $N$. sativa and propolis for 4 weeks is illustrated in Table 1. The mean values of serum fasting blood sugar (FBS) were significantly $(P<0.001)$ increased in the positive control group, when compared with those of the negative control. However, treating these rats with methanolic extract of $N$. sativa and propolis for 4 weeks significantly $(P<0.001)$ reduced the fasting blood sugar in the serum of both G3 and G4 groups, respectively, although being higher than that of the negative control values. Methanolic extract of propolis in G4 was more effective in reducing fasting blood sugar than that of $N$. sativa in G3.

3.3. Lipid Peroxide. Table 1 also shows the effect of treating diabetic rats with methanolic extracts of $N$. sativa and propolis for 4 weeks on lipid peroxidation (MDA) in the serum and kidney tissue homogenate. The mean values of MDA in the diabetic positive control (STZ treated) group were significantly $(P<0.001)$ increased compared with those of the negative control group in both serum and kidney tissue homogenate. In G3 and G4, the mean values of MDA in both 
TABLE 1: Effect of treating diabetic rats with methanolic extracts of $N$. sativa and propolis for 4 weeks on fasting blood sugar, lipid peroxide, and antioxidants enzymes.

\begin{tabular}{|c|c|c|c|c|c|}
\hline Parameters & Statistics & $\begin{array}{c}\text { G1 } \\
\text { N. control } \\
\end{array}$ & $\begin{array}{c}\mathrm{G} 2 \\
\text { P. control } \\
\end{array}$ & $\begin{array}{c}\mathrm{G} 3 \\
\text { Nigella sativa extract }\end{array}$ & $\begin{array}{c}\text { G4 } \\
\text { Propolis extract } \\
\end{array}$ \\
\hline \multirow{4}{*}{ Serum FBS (mL/dL) } & Mean \pm SE & & & & \\
\hline & LSD & $92.66 \pm 1.14^{\mathrm{d}}$ & $283.33 \pm 2.47^{\mathrm{a}}$ & $203.16 \pm 3.71^{b}$ & $139.00 \pm 1.18^{\mathrm{c}}$ \\
\hline & $0.05=7.230$ & & & & \\
\hline & $t$-test & - & $-63.63^{* * *}$ & $15.32^{* * *}$ & $59.03^{* * *}$ \\
\hline \multirow{4}{*}{ Serum MDA (nmol/mL) } & Mean \pm SE & & & & \\
\hline & LSD & $0.93 \pm 0.03^{\mathrm{d}}$ & $4.50 \pm 0.05^{\mathrm{a}}$ & $2.82 \pm 0.03^{\mathrm{b}}$ & $1.94 \pm 0.03^{\mathrm{c}}$ \\
\hline & $0.05=0.149$ & & & & \\
\hline & $t$-test & - & $-52.66^{* * *}$ & $20.35^{* * *}$ & $27.91^{* * *}$ \\
\hline \multirow{4}{*}{$\begin{array}{l}\text { MDA (nmol/g) } \\
\text { Kidney tissue }\end{array}$} & Mean \pm SE & & & & \\
\hline & LSD & $2.58 \pm 0.06^{\mathrm{d}}$ & $16.08 \pm 0.18^{\mathrm{a}}$ & $4.76 \pm 0.05^{\mathrm{b}}$ & $3.54 \pm 0.11^{\mathrm{c}}$ \\
\hline & $0.05=0.306$ & & & & \\
\hline & $t$-test & - & $-70.12^{* * *}$ & $67.64^{* * *}$ & $62.91^{* * *}$ \\
\hline \multirow{4}{*}{ Serum CAT (U/mL) } & Mean \pm SE & & & & \\
\hline & LSD & $2.40 \pm 0.19^{\mathrm{a}}$ & $0.15 \pm 0.01^{\mathrm{d}}$ & $1.20 \pm 0.01^{\mathrm{c}}$ & $1.89 \pm 0.02^{b}$ \\
\hline & $0.05=0.301$ & & & & \\
\hline & $t$-test & - & $11.49^{* * *}$ & $-71.53^{* * *}$ & $-58.72^{* * *}$ \\
\hline \multirow{4}{*}{ Serum SOD (U/mL) } & Mean \pm SE & & & & \\
\hline & LSD & $638.68 \pm 1.56^{\mathrm{a}}$ & $120.83 \pm 2.41^{\mathrm{d}}$ & $276.45 \pm 2.37^{\mathrm{c}}$ & $520.18 \pm 1.85^{\mathrm{b}}$ \\
\hline & $0.05=25.419$ & & & & \\
\hline & $t$-test & - & $178.65^{* * *}$ & $-48.94^{* * *}$ & $-116.79^{* * *}$ \\
\hline \multirow{4}{*}{ Serum GST (U/mL) } & Mean \pm SE & & & & \\
\hline & LSD & $813.20 \pm 2.32^{\mathrm{a}}$ & $120.93 \pm 2.38^{\mathrm{d}}$ & $421.56 \pm 3.20^{\mathrm{c}}$ & $762.65 \pm 1.74^{\mathrm{b}}$ \\
\hline & $0.05=6.450$ & & & & \\
\hline & t-test & - & $228.70^{* * *}$ & $-136.08^{* * *}$ & $-275.19^{* * *}$ \\
\hline \multirow{4}{*}{$\begin{array}{l}\text { CAT (U/g) } \\
\text { Kidney tissue }\end{array}$} & Mean \pm SE & & & & \\
\hline & LSD & $5.02 \pm 0.08^{\mathrm{a}}$ & $0.385 \pm 0.02^{c}$ & $2.86 \pm 0.03^{\mathrm{d}}$ & $3.97 \pm 0.06^{\mathrm{b}}$ \\
\hline & $0.05=0.144$ & & & & \\
\hline & $t$-test & - & $51.41^{* * *}$ & $-74.97^{* * *}$ & $-56.95^{* * *}$ \\
\hline \multirow{4}{*}{$\begin{array}{l}\text { SOD }(U / g) \\
\text { Kidney tissue }\end{array}$} & Mean \pm SE & & & & \\
\hline & LSD & $917.18 \pm 2.59^{\mathrm{a}}$ & $175.58 \pm 4.53^{\mathrm{d}}$ & $675.98 \pm 3.94^{\mathrm{c}}$ & $818.73 \pm 4.78^{\mathrm{b}}$ \\
\hline & $0.05=12.818$ & & & & \\
\hline & $t$-test & - & $117.11^{* * *}$ & $-134.00^{* * *}$ & $-88.10^{* * *}$ \\
\hline \multirow{4}{*}{$\begin{array}{l}\text { GST (U/g) } \\
\text { Kidney tissue }\end{array}$} & Mean \pm SE & & & & \\
\hline & LSD & $826.20 \pm 2.75^{\mathrm{a}}$ & $315.68 \pm 3.56^{\mathrm{c}}$ & $684.33 \pm 1.99^{\mathrm{b}}$ & $771.88 \pm 2.69^{\mathrm{ab}}$ \\
\hline & $0.05=181.965$ & & & & \\
\hline & $t$-test & - & $109.14^{* * *}$ & $-71.07^{* * *}$ & $-103.53^{* * *}$ \\
\hline
\end{tabular}

Data are represented as mean \pm SE. $t$-test values: $* * *$ : significant at $P<0.001$. ANOVA analysis: within each row, means with different superscript (a, b, c, or d) are significantly different at $P<0.05$, whereas means with the same superscript letters mean that there is no significant difference at $P<0.05$. LSD: least significant difference; NS: nonsignificant.

serum and kidney tissue homogenate were significantly $(P<$ 0.001 ) decreased compared to those of the positive control group as a result of treating diabetic rats with $N$. sativa and propolis methanolic extract, respectively.

Treating diabetic rats with the methanolic extract of propolis in G4 was more effective on lipid peroxidation compared to that of $N$. sativa in G3.
3.4. Antioxidant Enzymes. The results of treating diabetic rats with methanolic extracts of $N$. sativa and propolis for 4 weeks on antioxidant enzymes in the serum and kidney tissue are given in Table 1 . The mean values of catalase (CAT), superoxide dismutase (SOD), and glutathione-S-transferase (GST) in the positive control group were significantly $(P<$ 0.001) decreased compared to those of the negative control. 
TABLE 2: Effect of treating diabetic rats with methanolic extracts of N. sativa and propolis for 4 weeks on immunoglobulins and IL-6.

\begin{tabular}{|c|c|c|c|c|c|}
\hline Parameters & Statistics & $\begin{array}{c}\text { G1 } \\
\text { N. control } \\
\end{array}$ & $\begin{array}{c}\mathrm{G} 2 \\
\text { P. control } \\
\end{array}$ & $\begin{array}{c}\text { G3 } \\
\text { Nigella sativa extract } \\
\end{array}$ & $\begin{array}{c}\mathrm{G} 4 \\
\text { Propolis extract } \\
\end{array}$ \\
\hline \multirow{4}{*}{ Serum IgG (mg/dL) } & Mean \pm SE & & & & \\
\hline & LSD & $530.66 \pm 1.05^{\mathrm{b}}$ & $754.33 \pm 3.46^{\mathrm{a}}$ & $595.00 \pm 100.64^{b}$ & $572.33 \pm 2.40^{\mathrm{b}}$ \\
\hline & $0.05=152.870$ & & & & \\
\hline & $t$-test & - & $-63.91^{* * *}$ & $1.55^{\mathrm{NS}}$ & $45.12^{* * *}$ \\
\hline \multirow{4}{*}{ Serum IgA (mg/dL) } & Mean \pm SE & & & & \\
\hline & LSD & $99.16 \pm 1.88^{\mathrm{d}}$ & $359.83 \pm 1.74^{\mathrm{a}}$ & $257.00 \pm 1.73^{\mathrm{b}}$ & $126.00 \pm 1.31^{\mathrm{c}}$ \\
\hline & $0.05=5.492$ & & & & \\
\hline & $t$-test & - & $-85.42^{* * *}$ & $52.10^{* * *}$ & $92.71^{* * *}$ \\
\hline \multirow{4}{*}{ Serum IgM (mg/dL) } & Mean \pm SE & & & & \\
\hline & LSD & $129.83 \pm 1.07^{\mathrm{d}}$ & $357.16 \pm 2.24^{\mathrm{a}}$ & $220.00 \pm 2.22^{\mathrm{b}}$ & $141.50 \pm 1.78^{\mathrm{c}}$ \\
\hline & $0.05=5.614$ & & & & \\
\hline & $t$-test & - & $-138.06^{* * *}$ & $45.31^{* * *}$ & $65.29^{* * *}$ \\
\hline \multirow{4}{*}{ Serum IL-6 (pg/mL) } & Mean \pm SE & & & & \\
\hline & LSD & $5.60 \pm 0.26^{\mathrm{d}}$ & $24.48 \pm 0.89^{\mathrm{a}}$ & $11.90 \pm 0.34^{\mathrm{b}}$ & $8.78 \pm 0.19^{c}$ \\
\hline & $0.05=1.630$ & & & & \\
\hline & $t$-test & - & $-17.24^{* * *}$ & $11.26^{* * *}$ & $20.71^{* * *}$ \\
\hline \multirow{4}{*}{$\begin{array}{l}\text { IL6 }(\mathrm{pg} / \mathrm{g}) \\
\text { Kidney tissue }\end{array}$} & Mean \pm SE & & & & \\
\hline & LSD & $48.80 \pm 2.01^{\mathrm{d}}$ & $90.43 \pm 1.55^{\mathrm{a}}$ & $67.01 \pm 0.69^{\mathrm{b}}$ & $55.43 \pm 0.89^{c}$ \\
\hline & $0.05=4.285$ & & & & \\
\hline & $t$-test & - & $-14.14^{* * *}$ & $16.67^{* * *}$ & $19.38^{* * *}$ \\
\hline \multirow{4}{*}{$\begin{array}{l}\text { Carboxymethyl lysine } \\
(\mathrm{CML})(\mathrm{nmol} / \mathrm{mL})\end{array}$} & Mean \pm SE & & & & \\
\hline & LSD & $188.16 \pm 2.38^{\mathrm{d}}$ & $276.00 \pm 2.58^{\mathrm{a}}$ & $234.33 \pm 1.85^{\mathrm{b}}$ & $212.16 \pm 2.35^{\mathrm{c}}$ \\
\hline & $0.05=6.574$ & & & & \\
\hline & $t$-test & - & $-24.84^{* * *}$ & $10.93^{* * *}$ & $23.52^{* * *}$ \\
\hline
\end{tabular}

Data are represented as mean \pm SE. $t$-test values superscripts (a, b, c, or d) are significantly different at $P<0.05$, whereas means with the same superscript letters mean that there is no significant difference at $P<0.05$. LSD: least significant difference; NS: nonsignificant.

In G3 and G4, the mean values of CAT, SOD, and GST in the serum were significantly $(P<0.001)$ increased compared to those of the positive control as a result of treating diabetic rats with $N$. sativa and propolis methanolic extract, respectively. In $\mathrm{G} 4$, the mean values of the three antioxidant enzymes were higher than those of G3.

3.5. Interleukin-6 (IL-6). Table 2 shows the effect of treating diabetic rats with methanolic extracts of $N$. sativa and propolis for 4 weeks on interleukin-6 (IL-6) in the serum and kidney tissue homogenate. The mean values of IL-6 in the diabetic positive control group (G2) were significantly $(P<0.001)$ increased. After treating these diabetic rats with methanolic extracts of $N$. sativa and propolis in G3 and G4, respectively, a significant $(P<0.001)$ decrease in IL- 6 values compared with the positive control group was observed. Treating diabetic rats with propolis in G4 was more effective than treating them with $N$. sativa in G3.

3.6. Immunoglobulins (Igs). The effect of methanolic extracts of $N$. sativa and propolis on IgG, IgA, and IgM immunoglobulins in the serum with induced diabetic rats is given in Table 2. The mean values of IgG, IgA, and IgM immunoglobulins were significantly $(P<0.001)$ increased in the diabetic positive control (STZ treated) compared with those of the negative control group. In G3 and G4, the mean values of IgG, IgA, and IgM immunoglobulins were significantly $(P<0.001)$ decreased as a result of treatment with $N$. sativa and propolis methanolic extract, respectively. The immunoglobulins result revealed that treating STZ-induced diabetic rats with the propolis methanol extract in G4 was more efficient than treating them with the methanolic extract of $N$. sativa in G3.

3.7. Carboxymethyl Lysine (CML). The percentage of CML in the diabetic positive control group (G2) was significantly increased compared with negative control as shown in Table 2. In G3 and G4, the percentage of CML was very highly significantly $(P<0.001)$ decreased as a result of treating diabetic rats with $N$. sativa and propolis, respectively, compared with the positive control group. In G4, treating diabetic rats with methanolic extract of propolis was more effective on CML compared to treating them with $N$. sativa in G3.

3.8. Kidney Functions. The mean values of urea, creatinine, and uric acid in the serum of the positive control group 
TABLE 3: Effect of treating diabetic rats with methanolic extracts of N. sativa and propolis for 4 weeks on kidney functions and electrolytes.

\begin{tabular}{|c|c|c|c|c|c|}
\hline Parameters & Statistics & $\begin{array}{c}\text { G1 } \\
\text { N. control } \\
\end{array}$ & $\begin{array}{c}\text { G2 } \\
\text { P. control }\end{array}$ & $\begin{array}{c}\mathrm{G} 3 \\
\text { N. sativa extract }\end{array}$ & $\begin{array}{c}\text { G4 } \\
\text { Propolis extract }\end{array}$ \\
\hline \multirow{4}{*}{ Serum urea (mg/dL) } & Mean \pm SE & & & & \\
\hline & LSD & $24.50 \pm 1.11^{\mathrm{d}}$ & $74.83 \pm 0.87^{\mathrm{a}}$ & $47.33 \pm 0.88^{\mathrm{b}}$ & $33.33 \pm 0.98^{c}$ \\
\hline & $0.05=2.705$ & & & & \\
\hline & $t$-test & - & $-29.16^{* * *}$ & $25.28^{* * *}$ & $27.26^{* * *}$ \\
\hline \multirow{4}{*}{ Serum creatinine (mg/dL) } & Mean \pm SE & & & & \\
\hline & LSD & $0.68 \pm 0.03^{\mathrm{d}}$ & $3.63 \pm 0.18^{\mathrm{a}}$ & $2.60 \pm 0.09^{b}$ & $1.21 \pm 0.04^{\mathrm{c}}$ \\
\hline & $0.05=0.318$ & & & & \\
\hline & $t$-test & - & $-14.90^{* * *}$ & $6.70^{* * *}$ & $11.66^{* * *}$ \\
\hline \multirow{4}{*}{ Serum uric acid (mg/dL) } & Mean \pm SE & & & & \\
\hline & LSD & $3.33 \pm 0.08^{\mathrm{d}}$ & $6.68 \pm 0.04^{\mathrm{a}}$ & $5.15 \pm 0.07^{\mathrm{b}}$ & $4.20 \pm 0.05^{\mathrm{c}}$ \\
\hline & $0.05=0.179$ & & & & \\
\hline & $t$-test & - & $-59.53^{* * *}$ & $31.01^{* * *}$ & $28.46^{* * *}$ \\
\hline \multirow{4}{*}{ Urinary albumin (mg/dL) } & Mean \pm SE & & & & \\
\hline & LSD & $22.16 \pm 1.70^{\mathrm{d}}$ & $411.50 \pm 7.74^{\mathrm{a}}$ & $216.66 \pm 3.71^{d}$ & $122.66 \pm 3.27^{b}$ \\
\hline & $0.05=14.333$ & & & & \\
\hline & $t$-test & - & $-47.24^{* * *}$ & $20.85^{* * *}$ & $29.03^{* * *}$ \\
\hline \multirow{4}{*}{ Urinary creatinine $(\mathrm{mg} / \mathrm{dL})$} & Mean \pm SE & & & & \\
\hline & LSD & $85.00 \pm 0.85^{\mathrm{a}}$ & $27.00 \pm 0.36^{c}$ & $35.16 \pm 1.16^{\mathrm{b}}$ & $73.16 \pm 0.60^{c}$ \\
\hline & $0.05=2.405$ & & & & \\
\hline & $t$-test & - & $84.90^{* * *}$ & $-7.57^{* * *}$ & $-70.58^{* * *}$ \\
\hline \multirow{4}{*}{ Serum $\mathrm{Na}^{+}(\mathrm{mmol} / \mathrm{L})$} & Mean \pm SE & & & & \\
\hline & LSD & $143.83 \pm 0.94^{\mathrm{a}}$ & $118.33 \pm 0.88^{\mathrm{d}}$ & $127.83 \pm 0.60^{c}$ & $138.66 \pm 0.42^{\mathrm{b}}$ \\
\hline & $0.05=1.996$ & & & & \\
\hline & $t$-test & - & $19.85^{* * *}$ & $-8.99^{* * *}$ & $-24.11^{* * *}$ \\
\hline \multirow{4}{*}{ Serum $\mathrm{K}^{+}(\mathrm{mmol} / \mathrm{L})$} & Mean \pm SE & & & & \\
\hline & LSD & $4.86 \pm 0.03^{\mathrm{a}}$ & $3.03 \pm 0.08^{\mathrm{d}}$ & $3.76 \pm 0.04^{\mathrm{c}}$ & $4.25 \pm 0.04^{\mathrm{b}}$ \\
\hline & $0.05=0.169$ & & & & \\
\hline & $t$-test & - & $17.39^{* * *}$ & $-10.25^{* * *}$ & $-13.37^{* * *}$ \\
\hline
\end{tabular}

Data are represented as mean \pm SE. $t$-test values: $* * *$ : significant at $P<0.001$. ANOVA analysis: within each row, means with different superscript $(\mathrm{a}, \mathrm{b}, \mathrm{c}$, or d) are significantly different at $P<0.05$, whereas means with the same superscript letters mean that there is no significant difference at $P<0.05$. LSD: least significant difference; NS: nonsignificant.

(G2) were significantly $(P<0.001)$ increased compared with those of the negative control group (G1) as a result of induced diabetes shown in Table 3. Treating these diabetic rats with methanolic extracts of $N$. sativa and propolis in G3 and G4, respectively, significantly $(P<0.001)$ decreased urea, creatinine, and uric acid levels compared with those of the positive control group (G2). The methanolic extract of propolis in G4 was more effective than that of $N$. sativa in G3.

Also, Table 3 shows that the mean values of urinary albumin of the positive control group were significantly $(P<$ 0.001 ) increased compared with those of the negative control group (G1). Meanwhile, the mean values of urinary creatinine in $\mathrm{G} 2$ were significantly $(P<0.001)$ decreased compared with those of the negative control group (G1). Treating these diabetic rats in G3 and G4 with methanolic extract of $N$. sativa and propolis, respectively, significantly $(P<0.001)$ decreased urinary albumin and increased creatinine in urine when compared with those of the positive control (G2).

3.9. Serum Electrolytes. Table 3 also shows the effect of treating diabetic rats with methanolic extracts of $N$. sativa and propolis for 4 weeks on serum electrolytes. The mean values of serum sodium and potassium ions of the positive group were significantly $(P<0.001)$ decreased compared with those of the negative control group. Treating these diabetic rats with methanolic extracts of $N$. sativa and propolis in G3 and G4, respectively, significantly $(P<0.001)$ increased serum electrolytes levels $\left(\mathrm{Na}^{+}\right.$and $\left.\mathrm{K}^{+}\right)$compared with those of the positive control group.

3.10. Food Intake. Table 4 shows that there were nonsignificant differences in food intake (FI) in all groups in the first and the second week, whereas the mean values of FI in all 
TABLE 4: Effect of treating diabetic rats with methanolic extracts of N. sativa and propolis for 4 weeks on food intake.

\begin{tabular}{|c|c|c|c|c|c|}
\hline Food intake (g/day) & Statistics & $\begin{array}{c}\mathrm{G} 1 \\
\text { N. control } \\
\end{array}$ & $\begin{array}{c}\mathrm{G} 2 \\
\text { P. control }\end{array}$ & $\begin{array}{c}\mathrm{G} 3 \\
\text { N. sativa extract }\end{array}$ & $\begin{array}{c}\text { G4 } \\
\text { Propolis extract } \\
\end{array}$ \\
\hline \multirow{4}{*}{ 1st week } & Mean \pm SE & & & & \\
\hline & LSD & $15.50 \pm 0.22^{\mathrm{a}}$ & $15.50 \pm 0.22^{\mathrm{a}}$ & $15.50 \pm 0.22^{\mathrm{a}}$ & $15.50 \pm 0.22^{\mathrm{a}}$ \\
\hline & $0.05=0.674$ & & & & \\
\hline & $t$-test & - & $0.00^{\mathrm{NS}}$ & $0.00^{\mathrm{NS}}$ & $0.00^{\mathrm{NS}}$ \\
\hline \multirow{4}{*}{ 2nd week } & Mean \pm SE & & & & \\
\hline & LSD & $16.50 \pm 0.22^{\mathrm{a}}$ & $16.33 \pm 0.21^{\mathrm{a}}$ & $16.66 \pm 0.21^{\mathrm{a}}$ & $16.50 \pm 0.22^{\mathrm{a}}$ \\
\hline & $0.05=0.648$ & & & & \\
\hline & t-test & - & $0.54^{\mathrm{NS}}$ & $-1.58^{\mathrm{NS}}$ & $-0.54^{\mathrm{NS}}$ \\
\hline \multirow{4}{*}{ 3rd week } & Mean \pm SE & & & & \\
\hline & LSD & $19.16 \pm 0.54^{\mathrm{a}}$ & $18.16 \pm 0.40^{\mathrm{b}}$ & $17.00 \pm 0.44^{\mathrm{c}}$ & $15.50 \pm 0.22^{c}$ \\
\hline & $0.05=0.933$ & & & & \\
\hline & $t$-test & - & $3.87^{* *}$ & $2.90^{* *}$ & $6.32^{* * *}$ \\
\hline \multirow{4}{*}{ 4th week } & Mean \pm SE & $16.41 \pm 0.39^{\mathrm{a}}$ & $16.12 \pm 0.30^{\mathrm{ab}}$ & $15.95 \pm 0.23^{b}$ & $15.91 \pm 0.24^{\mathrm{b}}$ \\
\hline & LSD & & & & \\
\hline & $0.05=0.426$ & - & $1.77^{*}$ & $0.81^{\mathrm{NS}}$ & $1.15^{\mathrm{NS}}$ \\
\hline & $t$-test & & & & \\
\hline
\end{tabular}

Data are represented as mean \pm SE. $t$-test values: $*$ : significant at $P<0.05, * *$ : significant at $P<0.01$, and $* * *$ : significant at $P<0.001$. ANOVA analysis: within each row, means with different superscript (a, b, c, or d) are significantly different at $P<0.05$, whereas means with the same superscript letters mean that there is no significant difference at $P<0.05$. LSD: least significant difference; NS: nonsignificant.

TABLE 5: Effect of treating diabetic rats with methanolic extracts of N. sativa and propolis for 4 weeks on water consumption.

\begin{tabular}{|c|c|c|c|c|c|}
\hline Water consumed (mL/day) & Statistics & $\begin{array}{c}\text { G1 } \\
\text { N. control }\end{array}$ & $\begin{array}{c}\text { G2 } \\
\text { P. control }\end{array}$ & $\begin{array}{c}\mathrm{G} 3 \\
\text { N. sativa extract }\end{array}$ & $\begin{array}{c}\text { G4 } \\
\text { Propolis extract }\end{array}$ \\
\hline \multirow{4}{*}{ 1st week } & Mean \pm SE & & & & \\
\hline & LSD & $33.33 \pm 1.05^{\mathrm{b}}$ & $42.50 \pm 1.11^{\mathrm{a}}$ & $36.33 \pm 0.88^{\mathrm{b}}$ & $36.33 \pm 0.88^{b}$ \\
\hline & $0.05=3.257$ & & & & \\
\hline & $t$-test & - & $-4.56^{* * *}$ & $7.40^{* * *}$ & $4.01^{* *}$ \\
\hline \multirow{4}{*}{ 2nd week } & Mean \pm SE & & & & \\
\hline & LSD & $35.33 \pm 1.17^{\mathrm{b}}$ & $42.50 \pm 1.11^{\mathrm{a}}$ & $34.83 \pm 0.90^{\mathrm{b}}$ & $37.16 \pm 0.79^{b}$ \\
\hline & $0.05=2.943$ & & & & \\
\hline & $t$-test & - & $-4.73^{* * *}$ & $5.54^{* * *}$ & $4.54^{* * *}$ \\
\hline \multirow{4}{*}{ 3rd week } & Mean \pm SE & & & & \\
\hline & LSD & $29.16 \pm 1.53^{b}$ & $42.50 \pm 1.11^{\mathrm{a}}$ & $26.66 \pm 1.66^{\mathrm{b}}$ & $26.66 \pm 1.05^{\mathrm{b}}$ \\
\hline & $0.05=3.725$ & & & & \\
\hline & $t$-test & - & $-8.00^{* * *}$ & $7.88^{* * *}$ & $19.00^{* * *}$ \\
\hline \multirow{4}{*}{4 th week } & Mean \pm SE & & & & \\
\hline & LSD & $27.50 \pm 1.11^{\mathrm{a}}$ & $29.16 \pm 1.53^{\mathrm{a}}$ & $28.00 \pm 1.00^{\mathrm{a}}$ & $27.50 \pm 1.11^{\mathrm{a}}$ \\
\hline & $0.05=4.453$ & & & & \\
\hline & $t$-test & - & $-1.58^{\mathrm{NS}}$ & $0.63^{\mathrm{NS}}$ & $1.00^{\mathrm{NS}}$ \\
\hline
\end{tabular}

Data are represented as mean \pm SE. $t$-test values: $* *$ : significant at $P<0.01$ and $* * *$ : significant at $P<0.001$. ANOVA analysis: within each row, means with different superscript (a, b, c, or d) are significantly different at $P<0.05$, whereas means with the same superscript letters mean that there is no significant difference at $P<0.05$. LSD: least significant difference; NS: nonsignificant.

groups in the 3rd week were significantly $(P<0.01)$ lower than those of the negative control. In the fourth, FI of the positive control group was significantly $(P<0.05)$ lower than that of the negative control group. In G3 and G4, FI was nonsignificantly lower than that of the positive control group.
3.11. Water Consumption. Data in Table 5 illustrate the effect of supplementation of methanolic extract of $N$. sativa and propolis for 4 weeks to diabetic rats on water consumption. The positive control group showed significant $(P<0.001)$ increase in water consumption in the first three weeks as a 
TABLE 6: Effect of treating diabetic rats with methanolic extracts of $N$. sativa and propolis for 4 weeks on body weight gain (BWG) and food efficiency ratio (FER).

\begin{tabular}{|c|c|c|c|c|c|}
\hline Biological evaluation & Statistics & $\begin{array}{c}\text { G1 } \\
\text { N. control } \\
\end{array}$ & $\begin{array}{c}\mathrm{G} 2 \\
\text { P. control } \\
\end{array}$ & $\begin{array}{c}\mathrm{G} 3 \\
\text { N. sativa extract }\end{array}$ & $\begin{array}{c}\mathrm{G} 4 \\
\text { Propolis extract }\end{array}$ \\
\hline \multirow{4}{*}{ BWG (g/day) } & Mean \pm SE & $0.494 \pm 0.040^{\mathrm{a}}$ & $0.466 \pm 0.024^{\mathrm{a}}$ & $0.316 \pm 0.044^{\mathrm{a}}$ & $0.444 \pm 0.126^{\mathrm{a}}$ \\
\hline & LSD & & & & \\
\hline & $0.05=0.191$ & - & $0.57^{\mathrm{NS}}$ & $3.08^{* *}$ & $0.17^{\mathrm{NS}}$ \\
\hline & $t$-test & & & & \\
\hline \multirow{4}{*}{ BWG (g/4 week) } & Mean \pm SE & & & & \\
\hline & LSD & $14.833 \pm 1.222^{\mathrm{a}}$ & $14.000 \pm 0.730^{\mathrm{a}}$ & $9.500 \pm 1.335^{\mathrm{a}}$ & $13.333 \pm 3.783^{\mathrm{a}}$ \\
\hline & $0.05=5.735$ & & & & \\
\hline & $t$-test & - & $0.57^{\mathrm{NS}}$ & $3.09^{* *}$ & $0.17^{\mathrm{NS}}$ \\
\hline \multirow{4}{*}{ BWG\% } & Mean \pm SE & & & & \\
\hline & LSD & $8.305 \pm 0.685^{\mathrm{a}}$ & $7.059 \pm 0.436^{\mathrm{ab}}$ & $5.012 \pm 0.889^{b}$ & $6.818 \pm 1.988^{\mathrm{a}}$ \\
\hline & $0.05=2.178$ & & & & \\
\hline & $t$-test & - & $1.52^{\mathrm{NS}}$ & $2.15^{* *}$ & $0.12^{\mathrm{NS}}$ \\
\hline \multirow{4}{*}{ FER (g/day) } & Mean \pm SE & & & & \\
\hline & LSD & $0.030 \pm 0.002^{\mathrm{a}}$ & $0.029 \pm 0.001^{\mathrm{a}}$ & $0.020 \pm 0.002^{\mathrm{a}}$ & $0.028 \pm 0.007^{\mathrm{a}}$ \\
\hline & $0.05=0.011$ & & & & \\
\hline & $t$-test & - & $0.32^{\mathrm{NS}}$ & $3.09^{* *}$ & $0.12^{\mathrm{NS}}$ \\
\hline \multirow{4}{*}{ FER\% } & Mean \pm SE & & & & \\
\hline & LSD & $3.013 \pm 0.248^{\mathrm{a}}$ & $2.894 \pm 0.151^{\mathrm{a}}$ & $1.985 \pm 0.279^{\mathrm{a}}$ & $2.793 \pm 0.792^{\mathrm{a}}$ \\
\hline & $0.05=1.199$ & & & & \\
\hline & $t$-test & - & $0.40^{\mathrm{NS}}$ & $2.99^{* *}$ & $0.12^{\mathrm{NS}}$ \\
\hline
\end{tabular}

Data are represented as mean \pm SE. $t$-test values: $* *$ : significant at $P<0.01$. ANOVA analysis: within each row, means with different superscript $(\mathrm{a}, \mathrm{b}, \mathrm{c}$, or d) are significantly different at $P<0.05$, whereas means with the same superscript letters mean that there is no significant difference at $P<0.05$. LSD: least significant difference; NS: nonsignificant.

result of STZ-induced diabetes, compared with that of the negative control group, whereas the 4 th week showed no significant difference in water consumption in all groups. Treating diabetic rats with $N$. sativa and propolis significantly $(P<0.001)$ decreased water consumption, compared with that of positive group.

3.12. Physiological Evaluation. Table 6 shows the effect of treating STZ-induced diabetic rats with N. sativa and propolis for 4 weeks on physiological evaluation. The mean values of body weight gain (BWG), body weight gain percentage (BWG\%), food efficiency ratio (FER), and food efficiency ratio percentage (FER\%) in the positive control group were nonsignificantly lower than those of the negative control. Treating these diabetic rats with methanolic extract of $N$. sativa in G3 significantly $(P<0.01)$ decreased the mean values of these parameters when compared with the positive group, whereas the mean values of these parameters in G4 were nonsignificantly lower than those of the positive control group.

3.13. Pathology of Kidney. Microscopically, the histopathological examination of the kidney of the negative control group showed normal histological structure of normal kidney tissues and normal blood vessels with no histopathological changes (Figure 1(a)). Examination of kidney tissues of rats in the positive group, which suffer from diabetes, showed pathological changes in kidney structure compared to that of the negative control group. They showed a collapsed glomerular tuft with marked tubular atrophy associated with interstitial inflammation and interstitial hemorrhage (Figure 1(b)). Meanwhile, the kidney sections of diabetic rats in G3 treated with the $N$. sativa methanol extract for 4 weeks seemed to be restoring the normal appearance of glomeruli and regenerated tubules with interstitial hemorrhage (Figure $1(\mathrm{c}))$. On the other hand, after treatment with the propolis methanol extract in group (4) for 4 weeks, the kidney nearly restored the normal cortical tissue (Figure 1(d)).

3.14. Pathology of Pancreas. Figure 2 shows the histology of pancreas of rats under study. Figure 2(a) shows the normal pancreatic tissues of the negative control group (G1) with normal pancreatic acini, Langerhans cells, and interductal glands. Figure 2(b) shows the pancreatic tissues of the streptozotocin-induced diabetic rats of the positive control (G2) with degenerated pancreatic acini cells, periductal inflammation, and mild congested edema. Figure 2(c) shows the pancreas of diabetic rats treated with Nigella sativa (G3) with improvement in the degenerated pancreatic acini cells, mild inflammation, and congestion. Figure 2(d) shows the 




(a)

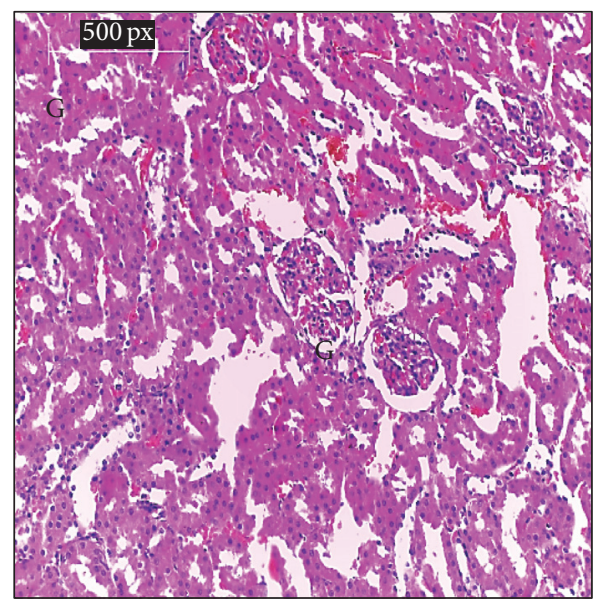

(c)



(b)

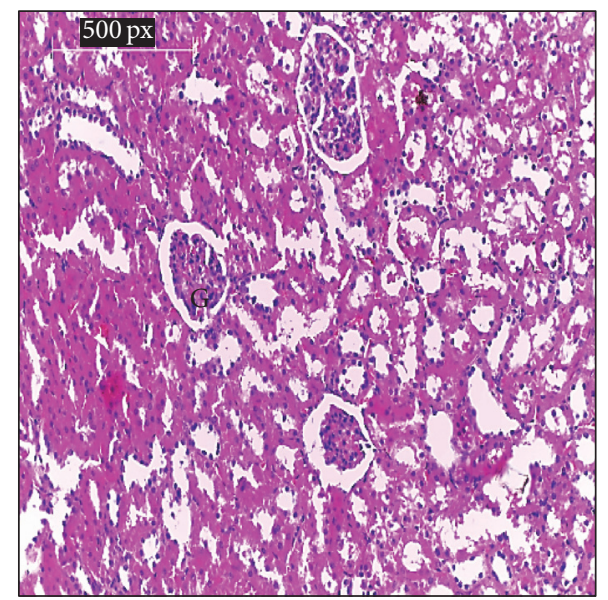

(d)

FIGURE 1: (a) Kidney of rats of the negative control group reveals the normal histological structure of renal tissue with normal parenchyma, normal blood vessels, and being interstitial with no histopathological changes, (b) kidney of rat from the positive control group showing collapsed glomerular tuft with marked tubular atrophy, interstitial inflammation, and interstitial hemorrhage, (c) kidney of diabetic rat treated with $N$. sativa methanol extract showing normal glomeruli and regenerated tubules with interstitial hemorrhage, and (d) kidney of diabetic rat treated with propolis methanol extract (G4) showing near normal renal cortical tissue. G: glomerulus (H\&E stain $\times 200)$.

pancreas of diabetic rats of the propolis treated group (G4) with no evidence of inflammation in islets or around the large ducts with normal pancreatic tissues.

\section{Discussion}

Diabetes mellitus is metabolic disorder leading to hyperglycemia, which later develops to micro- and macrovascular complications. The induction of experimental diabetes in the rats using chemicals which selectively destroy pancreatic $\beta$ cells is very convenient and simple to use as streptozotocin (STZ) that acts as diabetogenic agent mediated by reactive oxygen species [40]. In the present study, induction of diabetes using streptozotocin (STZ) at a dose of $65 \mathrm{mg} / \mathrm{kg}$ in rats of the positive control group showed significant increase in serum glucose level compared with the control group [3, 41]. The concurrent oral administration of $20 \%$ of methanolic extract of N. sativa or propolis to the diabetic rats of G3 and G4, respectively, for 4 weeks significantly decreased glucose levels most probably due to their antioxidant chemical contents $[42,43]$.

STZ diabetic rats in G2 also showed an increase in lipid peroxidation level accompanied by decreased CAT, SOD, and GST activity in the serum and the kidney tissue homogenate compared with that of the negative control group after 4 weeks. This result is in agreement with previous investigations $[3,4,44]$. This result may be attributed to the fact that the elevated generation of free radicals resulting in the consumption of antioxidant defense components may lead to disruption of cellular functions and oxidative damage to membranes and may enhance susceptibility to lipid peroxidation [45]. The concurrent treatment with methanolic extract of N. sativa and propolis ameliorated these parameters and nearly restored them to their normal levels as a result of 


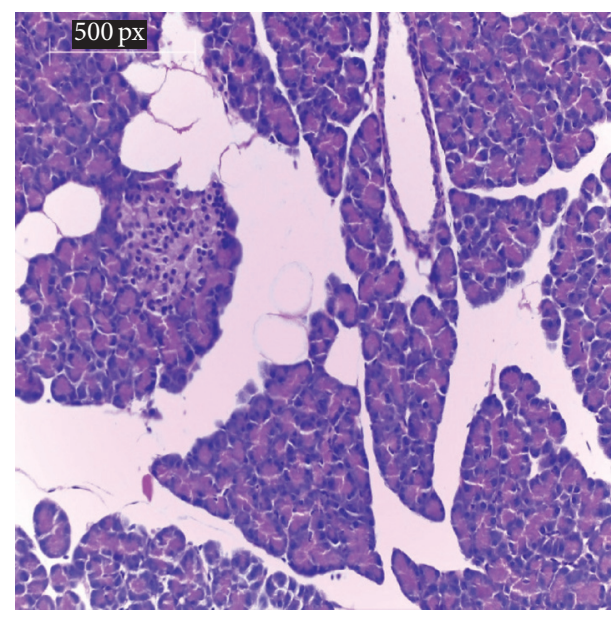

(a)

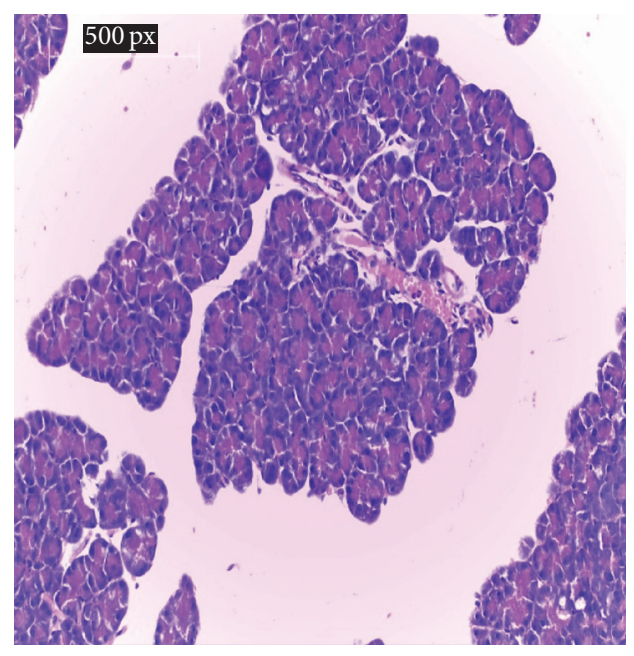

(c)

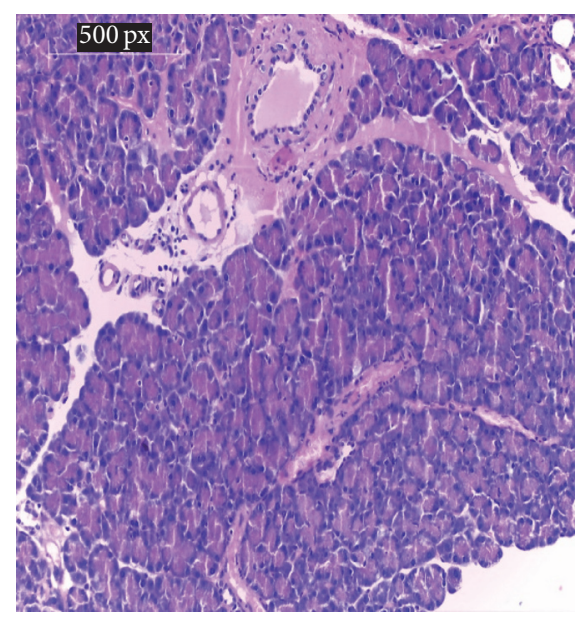

(b)

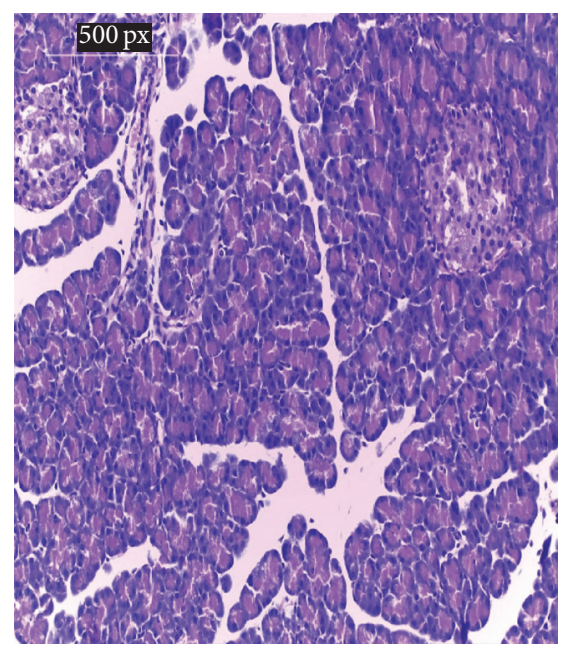

(d)

Figure 2: (a) Pancreas of control negative group showing normal pancreatic acini, Langerhans cells, and interductal glands. (b) Pancreas of control positive group showing mild degeneration of pancreatic acini cells with periductal inflammation, edema, and congestion. (c) Pancreas of Nigella sativa treated group showing improvement and degeneration of pancreatic tissues with nearly normal tissues. (d) Pancreas of propolis treated group showing restored pancreatic tissues to the normal with no evidence of inflammation in islets or around the large ducts. (H\&E, ×200).

their antioxidant activity due to their contents of phenolics and flavonoids that have scavenging effect on the free radicals [11, 46].

Advanced glycation end products (AGEs) increase reactive oxygen species formation and impair antioxidant systems that activate $\mathrm{NF}-\kappa \mathrm{B}$ signaling pathway which enhanced the production of the cytokine interleukin-6 (IL-6) involved not only in inflammation and infection responses but also in the regulation of metabolic, regenerative, and neural processes [47]. In the current study, IL-6 was increased in the serum and kidney tissue in positive group as a result of STZinduced diabetes. A similar result was reported by Sayed [34]. However, IL-6 was decreased with the concurrent treatment with methanolic extract of $N$. sativa and propolis. This result is consistent with Bashandy et al. [48] and Al Ghamdi et al. [49].
The increase of immunoglobulins (IgG, IgA, and IgM) as a result of diabetes in the current study is consistent with the increase in IL- 6 and other findings revealed a positive correlation between these parameters [3]. This may be attributed to the fact that production of proinflammatory cytokines is increased in patients with diabetes. These include adipocytokines such as interleukin-6 (IL-6), which is a cofactor for immunoglobulin synthesis and a common marker of inflammation [50]. Treating diabetic rats with $N$. sativa and propolis has significantly reduced immunoglobulins (IgG, $\operatorname{IgA}$, and $\operatorname{IgM})$. These results are consistent with previous studies $[51,52]$.

Diabetes is associated with severe acute and chronic complications that negatively influence both the quality of life and survival of affected individuals [53]. Therefore, protein glycation and formation of AGEs play an important role in 
the pathogenesis of diabetic complications like retinopathy, cataract, neuropathy, nephropathy, and cardiomyopathy [54]. $\mathrm{N} \mathcal{E}$-(Carboxymethyl) lysine (CML) was selected as a marker of AGEs in laboratory studies. In our study, CML showed significant increase in the untreated diabetic group after 4 weeks compared with the negative control. This result agrees with that of Van Eupen et al. [5]. On the other hand, our result showed that carboxymethyl lysine (CML) was significantly decreased in the treated diabetic group with N. sativa and propolis in G3 and G4, respectively, compared with the untreated diabetic group G2. It is worthy to mention that the efficacy of propolis on lowering carboxymethyl lysine (CML) exceeded that of $N$. sativa.

STZ administration increased serum renal markers in rats, for example, creatinine, urea, and uric acid $[3,55]$, as a result of diabetic nephropathy which is considered a major complication of diabetes [34]. The current investigation is consistent with the previous studies. Furthermore, overtime diabetic nephropathy will be developed which is characterized by proteinuria, a loss of renal function, and a rapid progression to end stage renal failure [7]. Urine analysis of the STZ-induced diabetes rats showed significant increase in albumin level in the positive control group and decreased urinary creatinine level in G2 after 4 weeks. These results are consistent with other studies $[3,56]$. Treatment with $N$. sativa and propolis as natural resources showed significant decrease in the levels of urea, creatinine, and uric acid compared with the positive control. The present results were in conformity with the results of Abdelaziz and Kandeel [57] and Saleh [58]. On other hand, oral administration of propolis revealed a significant reduction of urinary albumin and restoring urinary creatinine approaching the negative control level more than treatment with $N$. sativa. The effect of treatment with $20 \%$ of methanolic extract of propolis may be attributed to a strong antioxidant effect of propolis, which can ameliorate oxidative stress and delay the occurrence of diabetic nephropathy in diabetes mellitus $[59,60]$. The combination of intracellular and extracellular electrolyte disturbances may be implicated in the pathogenesis of neuropathy, nephropathy, and vascular complications in diabetic patients [61]. Our experiment recorded a significant decrease in serum sodium and potassium in the untreated diabetic group. This result agrees with previous investigation of Al-Rubeaan et al. [62] and Liamis et al. [63]. Diabetic rats treated with propolis restored serum electrolyte $\left(\mathrm{Na}^{+}\right.$and $\left.\mathrm{K}^{+}\right)$levels to normal compared to N. sativa.

The renal and pancreatic tissues were severely affected in hyperglycemic rats of G2 as a result of STZ supplementation. This result which is consistent with other studies showed a correlation between hyperglycemia and pathological alteration of vital organs $[64,65]$. The concurrent supplementation with N. sativa and propolis in G3 and G4, respectively, has significantly improved renal and pancreatic tissues and nearly restored them to their normal state $[66,67]$.

However, administration of $20 \%(\mathrm{w} / \mathrm{w})$ methanolic extract of either $N$. sativa or propolis to STZ-induced diabetic rats significantly reduced hyperglycemic and oxidative stress resulting from hyperglycemia. Also, they improved all adverse biochemical and histopathological changes resulting from diabetes. These natural resources revealed safe and excellent antidiabetic activity attributed to their antioxidant activity. As well as overcoming most of the histopathology changes in kidney and pancreas tissues, the majority of the cells restored the normal conditions. In addition, methanolic extract of propolis appeared to be more efficient than N. sativa as revealed by the different biochemical and histological investigations. Therefore, it is recommended that dietary $N$. sativa and propolis could be excellent adjuvant support in the therapy of diabetes mellitus and preventing its complications.

\author{
Abbreviations \\ AGEs: Advanced glycation end products \\ BUN: Blood urea nitrogen \\ BWG: Body weight gain \\ BWG\%: Body weight gain percentage \\ CAT: Catalase \\ CML: $\quad$ Ne-(Carboxymethyl) lysine \\ Cr: $\quad$ Creatinine \\ CVD: Cardiovascular disease \\ FBG: $\quad$ Fasting blood glucose \\ FER: Food efficiency ratio \\ FER\%: Food efficiency ratio percentage \\ G1: The first negative control group receiving a \\ single tail vein injection of $0.1 \mathrm{~mol} / \mathrm{L}$ \\ citrate buffer \\ G2: $\quad$ The second positive control diabetic group \\ intravenously injected with freshly \\ prepared streptozotocin $(60 \mathrm{mg} / \mathrm{kg}$ body \\ weight) in a $0.1 \mathrm{~mol} / \mathrm{L}$ citrate buffer $(\mathrm{pH}$ \\ 4.5) \\ G3: The third group, diabetic rats as in G2 \\ treated with $20 \%$ w/w Nigella sativa \\ methanolic extract for 4 weeks \\ G4: The fourth group, diabetic rats as in G2 \\ treated with $20 \% \mathrm{w} / \mathrm{w}$ propolis methanolic \\ extract for 4 weeks \\ GST: Glutathione-S-transferase \\ IDDM: Insulin-dependent diabetes mellitus \\ Igs: Immunoglobulins \\ IL-6: Interleukin-6 \\ MDA: Malondialdehyde \\ N. sativa: Nigella sativa \\ ROS: $\quad$ Reactive oxygen species \\ SOD: Superoxide dismutase \\ STZ: Streptozotocin.
}

\section{Competing Interests}

The authors of this paper declare that they have no competing interests.

\section{Acknowledgments}

The authors thank King Abdulaziz City for Science and Technology (KACST) for supporting this project (Grant no. 418-35- b I). Thanks are also due to DSR, KAU, for their help and technical support. 


\section{References}

[1] I. Vlad and A. R. Popa, "Epidemiology of diabetes mellitus: a current review," Romanian Journal of Diabetes, Nutrition and Metabolic Diseases, vol. 19, no. 4, pp. 433-440, 2012.

[2] A. H. Al-Assaf, "Antihyperglycemic and antioxidant effect of ginger extract on streptozotocin-diabetic rats," Pakistan Journal of Nutrition, vol. 11, no. 12, pp. 1107-1112, 2012.

[3] A. L. Al-Malki and H. A. El Rabey, "The antidiabetic effect of low doses of moringa oleifera lam. Seeds on streptozotocin induced diabetes and diabetic nephropathy in male rats," BioMed Research International, vol. 2015, Article ID 381040, 13 pages, 2015.

[4] A. L. Al-Malki, "Oat attenuation of hyperglycemia-induced retinal oxidative stress and NF- $\kappa \mathrm{B}$ activation in streptozotocininduced diabetic rats," Evidence-based Complementary and Alternative Medicine, vol. 2013, Article ID 983923, 8 pages, 2013.

[5] M. Van Eupen, M. Schram, H. Colhoun, J. Scheijen, C. Stehouwer, and C. Schalkwijk, "Plasma levels of advanced glycation end products are associated with type 1 diabetes and coronary artery calcification," Cardiovascular Diabetology, vol. 12, pp. 149-157, 2013.

[6] N. Khandouzi, F. Shidfar, A. Rajab, T. Rahideh, P. Hosseini, and M. M. Taheri, "The effects of ginger on fasting blood sugar, hemoglobin Alc, apolipoprotein B, apolipoprotein AI and malondialdehyde in type 2 diabetic patients," Iranian Journal of Pharmaceutical Research, vol. 14, no. 1, pp. 131-140, 2015.

[7] A. Al-Logmani and T. Zari, "Long-term effects of Nigella sativa $\mathrm{L}$. oil on some physiological parameters in normal and streptozotocin-induced diabetic rats," Journal of Diabetes Mellitus, vol. 1, no. 3, pp. 46-53, 2011.

[8] M. Kanter, I. Meral, Z. Yener, H. Ozbek, and H. Demir, "Partial regeneration/proliferation of the $\beta$-cells in the Islets of Langerhans by Nigella sativa L. in streptozotocin-induced diabetic rats," The Tohoku Journal of Experimental Medicine, vol. 201, no. 4, pp. 213-219, 2003.

[9] A. Bamosa, "A review on the hypoglycemic effect of Nigella sativa and thymoquinone," Saudi Journal of Medicine \& Medical Sciences, vol. 3, no. 1, pp. 2-7, 2015.

[10] M. A. Randhawa and M. S. Alghamdi, "Anticancer activity of Nigella sativa (black seed) - a review," The American Journal of Chinese Medicine, vol. 39, no. 6, pp. 1075-1091, 2011.

[11] C.-C. Toma, N.-K. Olah, L. Vlase, C. Mogoşan, and A. Mocan, "Comparative studies on polyphenolic composition, antioxidant and diuretic effects of nigella sativa L. (black cumin) and nigella damascena L. (Lady-in-a-Mist) seeds," Molecules, vol. 20, no. 6, pp. 9560-9574, 2015.

[12] N. Paulino, S. R. L. Abreu, Y. Uto et al., "Anti-inflammatory effects of a bioavailable compound, Artepillin C, in Brazilian propolis," European Journal of Pharmacology, vol. 587, no. 1-3, pp. 296-301, 2008.

[13] E. Gregoris and R. Stevanato, "Correlations between polyphenolic composition and antioxidant activity of Venetian propolis," Food and Chemical Toxicology, vol. 48, no. 1, pp. 76-82, 2010.

[14] B. Kouidhi, T. Zmantar, and A. Bakhrouf, "Anti-cariogenic and anti-biofilms activity of Tunisian propolis extract and its potential protective effect against cancer cells proliferation," Anaerobe, vol. 16, no. 6, pp. 566-571, 2010.
[15] L.-J. Kang, H. B. Lee, H.-J. Bae, and S.-G. Lee, "Antidiabetic effect of propolis: reduction of expression of glucose-6phosphatase through inhibition of Y279 and Y216 autophosphorylation of GSK-3 $\alpha / \beta$ in HepG2 cells," Phytotherapy Research, vol. 24, no. 10, pp. 1554-1561, 2010.

[16] P. Schnitzler, A. Neuner, S. Nolkemper et al., "Antiviral activity and mode of action of propolis extracts and selected compounds," Phytotherapy Research, vol. 24, no. 1, pp. 20-28, 2010.

[17] D. Skaba, T. Morawiec, M. Tanasiewicz et al., "Influence of the toothpaste with brazilian ethanol extract propolis on the oral cavity health," Evidence-based Complementary and Alternative Medicine, vol. 2013, Article ID 215391, 12 pages, 2013.

[18] E. Shruthi and B. S. Suma, "Health from the hive: potential uses of propolis in general health," International Journal of Clinical Medicine, vol. 3, no. 3, pp. 159-162, 2012.

[19] M. Dubois, K. A. Gilles, J. K. Hamilton, P. A. Rebers, and F. Smith, "Colorimetric method for determination of sugars and related substances," Analytical Chemistry, vol. 28, no. 3, pp. 350356, 1956.

[20] E. Adebayo, O. Ishola, O. Taiwo, O. Majolagbe, and B. Adekeye, "Evaluations of the methanol extract of Ficus exasperata stem bark, leaf and root for phytochemical analysis and antimicrobial," African Journal of Plant Science, vol. 3, no. 12, pp. 283-287, 2009.

[21] J. Zhishen, T. Mengcheng, and W. Jianming, “The determination of flavonoid contents in mulberry and their scavenging effects on superoxide radicals," Food Chemistry, vol. 64, no. 4, pp. 555$559,1999$.

[22] D. Barham and P. Trinder, "An improved colour reagent for the determination of blood glucose by the oxidase system," The Analyst, vol. 97, no. 1151, p. 142, 1972.

[23] H. Ohkawa, N. Ohishi, and K. Yagi, "Assay for lipid peroxides in animal tissues by thiobarbituric acid reaction," Analytical Biochemistry, vol. 95, no. 2, pp. 351-358, 1979.

[24] M. Nishikimi, N. Appaji Rao, and K. Yagi, "The occurrence of superoxide anion in the reaction of reduced phenazine methosulfate and molecular oxygen," Biochemical and Biophysical Research Communications, vol. 46, no. 2, pp. 849-854, 1972.

[25] H. Aebi, "Catalase in vitro," Methods in Enzymology, vol. 105, pp. 121-126, 1984.

[26] W. Habig, M. Pabst, and W. Jakoby, "Glutathione S-transferase: the first enzymatic step in mercapturic acid formation," The Journal of Biological Chemistry, vol. 249, no. 22, pp. 7130-7139, 1974.

[27] M. Hibi, K. Nakajima, and T. Hirano, "IL-6 cytokine family and signal transduction: a model of the cytokine system," Journal of Molecular Medicine, vol. 74, no. 1, pp. 1-12, 1996.

[28] J. L. Fahey and E. M. Mckelvey, "Quantitative determination of serum immunoglobulins in antibody-agar," The Journal of Immunology, vol. 94, pp. 84-90, 1965.

[29] G. Berne, "Detection of total IgG," Clinical Chemistry, vol. 200, pp. 61-89, 1974.

[30] L. J. Seigel, M. E. Harper, F. Wong-Staal, R. C. Gallo, W. G. Nash, and S. J. O'Brien, "Gene for T-cell growth factor: location on human chromosome 4q and feline chromosome B1," Science, vol. 223, no. 4632, pp. 175-178, 1984.

[31] J. K. Fawcett and J. E. Scott, "A rapid and precise method for the determination of urea," Journal of Clinical Pathology, vol. 13, pp. 156-159, 1960.

[32] H. Bartels, M. Bohmer, and C. Heierli, "Serum creatinine determination without protein precipitation," Clinica Chimica Acta, vol. 37, pp. 193-197, 1972. 
[33] P. Fossati, L. Prencipe, and G. Berti, "Use of 3,5-dichloro-2hydroxybenzenesulfonic acid/4-aminophenazone chromogenic system in direct enzymic assay of uric acid in serum and urine," Clinical Chemistry, vol. 26, no. 2, pp. 227-231, 1980.

[34] A. A. R. Sayed, "Ferulsinaic acid modulates SOD, GSH, and antioxidant enzymes in diabetic kidney," Evidence-Based Complementary and Alternative Medicine, vol. 2012, Article ID 580104, 9 pages, 2012.

[35] P. Trinder, "A rapid method for the determination of sodium in serum," The Analyst, vol. 76, no. 907, pp. 596-599, 1951.

[36] A. Terri and P. Sesin, "Determination of serum potassium by using sodium tetraphenylboro method," American Journal of Clinical Pathology, vol. 29, no. 1, pp. 86-90, 1958.

[37] B. Davies and T. Morris, "Physiological parameters in laboratory animals and humans," Pharmaceutical Research, vol. 10, no. 7, pp. 1093-1095, 1993.

[38] R. Drury, E. Wallington, and R. Cancerson, Carleton's Histological Technique, Oxford University Press, Oxford, UK, 4th edition, 1976.

[39] SAS (Statistical Analysis System), SAS User's Guide: Statistics, Version 5, SAS Institute, Cary, NC, USA, 1986.

[40] T. Szkudelski, "The mechanism of alloxan and streptozotocin action in B cells of the rat pancreas," Physiological Research, vol. 50, no. 6, pp. 537-546, 2001.

[41] C. O. Eleazu, K. C. Eleazu, S. Chukwuma, and U. N. Essien, "Review of the mechanism of cell death resulting from streptozotocin challenge in experimental animals, its practical use and potential risk to humans," Journal of Diabetes and Metabolic Disorders, vol. 12, no. 1, article 60, 2013.

[42] N. E. Abdelmeguid, R. Fakhoury, S. M. Kamal, and R. J. Al Wafai, "Effects of Nigella sativa and thymoquinone on biochemical and subcellular changes in pancreatic $\beta$-cells of streptozotocin-induced diabetic rats," Journal of Diabetes, vol. 2, no. 4, pp. 256-266, 2010.

[43] A. Abdulbasit, M. Oladayo, F. Olamide, O. Olasile, I. Babatunde, and B. Gbolahan, "Effect of Nigerian propolis on glycemia, lipid profile, and oxidative stress markers in alloxan-induced diabetic rats," Pharmacologyonline, vol. 2, pp. 149-158, 2013.

[44] D. Gomathi, M. Kalaiselvi, G. Ravikumar, K. Devaki, and C. Uma, "Evaluation of antioxidants in the kidney of streptozotocin induced diabetic rats," Indian Journal of Clinical Biochemistry, vol. 29, no. 2, pp. 221-226, 2014.

[45] P. Suryanarayana, A. Satyanarayana, N. Balakrishna, P. U. Kumar, and G. Bhanuprakash Reddy, "Effect of turmeric and curcumin on oxidative stress and antioxidant enzymes in streptozotocin-induced diabetic rat," Medical Science Monitor, vol. 13, no. 12, pp. BR286-BR292, 2007.

[46] M. G. Miguel, S. Nunes, S. A. Dandlen, A. M. Cavaco, and M. D. Antunes, "Phenols, flavonoids and antioxidant activity of aqueous and methanolic extracts of propolis (Apis mellifera L.) from Algarve, South Portugal," Food Science and Technology, vol. 34, no. 1, pp. 16-23, 2014.

[47] Y. J. Chen, M. L. Sheu, K. S. Tsai, R. S. Yang, and S. H. Liu, "Advanced glycation end products induce peroxisome proliferator-activated receptor $\gamma$ down-regulation-related inflammatory signals in human chondrocytes via toll-like receptor-4 and receptor for advanced glycation end products," PLoS ONE, vol. 8, no. 6, Article ID e66611, 2013.

[48] S. Bashandy, G. Jaleel, H. Abdallah, and S. Harraz, "Therapeutic implications of thymoquinone in the management of diabetes mellitus and its complications," American Journal of
Phytomedicine and Clinical Therapeutics, vol. 3, no. 3, pp. 287301, 2015.

[49] A. A. Al Ghamdi, G. Badr, W. N. Hozzein et al., "Oral supplementation of diabetic mice with propolis restores the proliferation capacity and chemotaxis of $\mathrm{B}$ and $\mathrm{T}$ lymphocytes towards CCL21 and CXCL12 by modulating the lipid profile, the pro-inflammatory cytokine levels and oxidative stress," $B M C$ Immunology, vol. 16, no. 1, article no. 54, 2015.

[50] A. Gonzalez-Quintela, R. Alende, F. Gude et al., "Serum levels of immunoglobulins (IgG, IgA, IgM) in a general adult population and their relationship with alcohol consumption, smoking and common metabolic abnormalities," Clinical and Experimental Immunology, vol. 151, no. 1, pp. 42-50, 2008.

[51] S. Scheller, G. Gazda, G. Pietsz et al., "The ability of ethanol extract of propolis to stimulate plaque formation in immunized mouse spleen cells," Pharmacological Research Communications, vol. 20, no. 4, pp. 323-328, 1988.

[52] K. M. Fararh, Y. Atoji, Y. Shimizu, T. Shiina, H. Nikami, and T. Takewaki, "Mechanisms of the hypoglycaemic and immunopotentiating effects of Nigella sativa L. oil in streptozotocininduced diabetic hamsters," Research in Veterinary Science, vol. 77, no. 2, pp. 123-129, 2004.

[53] P. Vigneri, F. Frasca, L. Sciacca, G. Pandini, and R. Vigneri, "Diabetes and cancer," Endocrine-Related Cancer, vol. 16, no. 4, pp. 1103-1123, 2009.

[54] V. P. Singh, A. Bali, N. Singh, and A. S. Jaggi, "Advanced glycation end products and diabetic complications," The Korean Journal of Physiology and Pharmacology, vol. 18, no. 1, pp. 1-14, 2014.

[55] T. Balasubramanian, "Therapeutic effect of stereospermum suavelolens on diabetic nephropathy," Clinical \& Experimental Pharmacology, vol. 4, no. 5, article no. 162, 2014.

[56] N. L. Alderson, M. E. Chachich, N. Frizzell et al., "Effect of antioxidants and ACE inhibition on chemical modification of proteins and progression of nephropathy in the streptozotocin diabetic rat," Diabetologia, vol. 47, no. 8, pp. 1385-1395, 2004.

[57] I. Abdelaziz and M. Kandeel, "The protective effects of Nigella sativa oil and Allium sativum extract on amikacin-induced nephrotoxicity," International Journal of Pharmacology, vol. 7, no. 6, pp. 697-703, 2011.

[58] E. Saleh, "Antioxidant effect of aqueous extract of propolis on hepatotoxicity induced by octylphenol in male rats," Acta Toxicológica Argentina, vol. 20, no. 2, pp. 68-81, 2012.

[59] O. Abo-Salem, R. H. El-Edel, G. Harisa, N. El-Halawany, and M. Ghonaim, "Experimental diabetic nephropathy can be prevented by propolis: effect on metabolic disturbances and renal oxidative parameters," Pakistan Journal of Pharmaceutical Sciences, vol. 22, no. 2, pp. 205-210, 2009.

[60] M. Premalatha and C. S. Parameswari, "Renoprotective effect of chrysin (5,7 dihydro flavone) in Streptozotocin induced diabetic nephropathy in rats," International Journal of Pharmacy and Pharmaceutical Sciences, vol. 4, no. 3, pp. 241-247, 2012.

[61] S. Wang, X. Hou, Y. Liu et al., "Serum electrolyte levels in relation to macrovascular complications in Chinese patients with diabetes mellitus," Cardiovascular Diabetology, vol. 12, pp. 146-155, 2013.

[62] K. Al-Rubeaan, K. Siddiqui, K. Abu Risheh et al., "Correlation between serum electrolytes and fasting glucose and HblAc in Saudi diabetic patients," Biological Trace Element Research, vol. 144, no. 1-3, pp. 463-468, 2011. 
[63] G. Liamis, E. Liberopoulos, F. Barkas, and M. Elisaf, "Diabetes mellitus and electrolyte disorders," World Journal of Clinical Cases, vol. 2, no. 10, pp. 488-496, 2014.

[64] S. K. Ramudu, M. Korivi, N. Kesireddy et al., "Nephroprotective effects of a ginger extract on cytosolic and mitochondrial enzymes against streptozotocin (STZ)-induced diabetic complications in rats," Chinese Journal of Physiology, vol. 54, no. 2, pp. 79-86, 2011.

[65] D. Ahmed, V. Kumar, A. Verma et al., "Antidiabetic, renal/ hepatic/pancreas/cardiac protective and antioxidant potential of methanol/dichloromethane extract of Albizzia Lebbeck Benth. stem bark (ALEx) on streptozotocin induced diabetic rats," BMC Complementary and Alternative Medicine, vol. 14, article no. 243, 2014.

[66] M. Kanter, "Protective effects of thymoquinone on streptozotocin-induced diabetic nephropathy," Journal of Molecular Histology, vol. 40, no. 2, pp. 107-115, 2009.

[67] M. Al-Hariri, T. A. G. Eldin, and M. Al-Harb, "Protective effect and potential mechanisms of propolis on streptozotocininduced diabetic rats," Journal of Taibah University Medical Sciences, vol. 11, no. 1, pp. 7-12, 2016. 


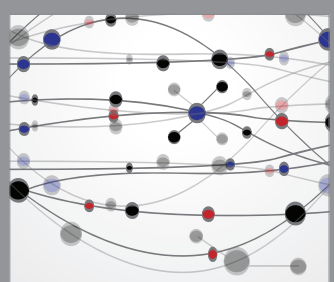

The Scientific World Journal
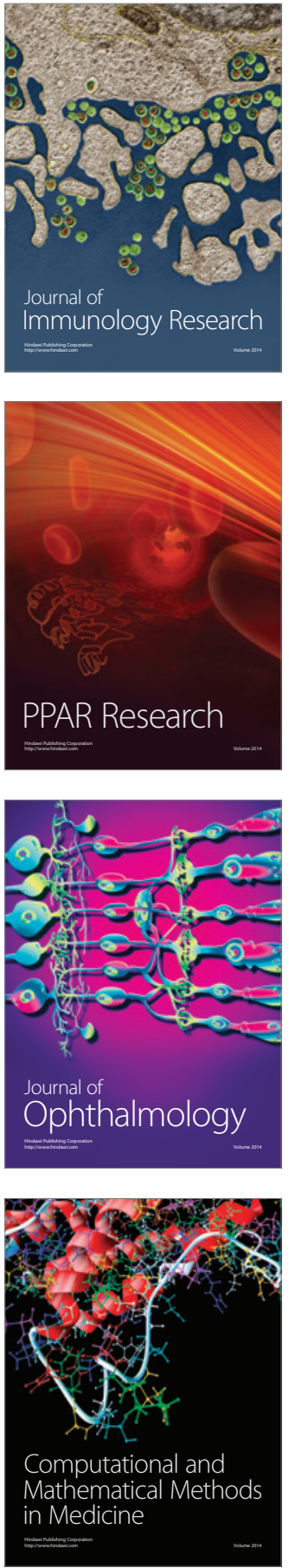

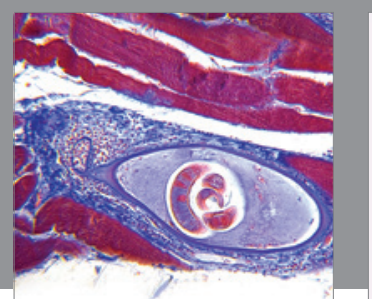

Gastroenterology Research and Practice
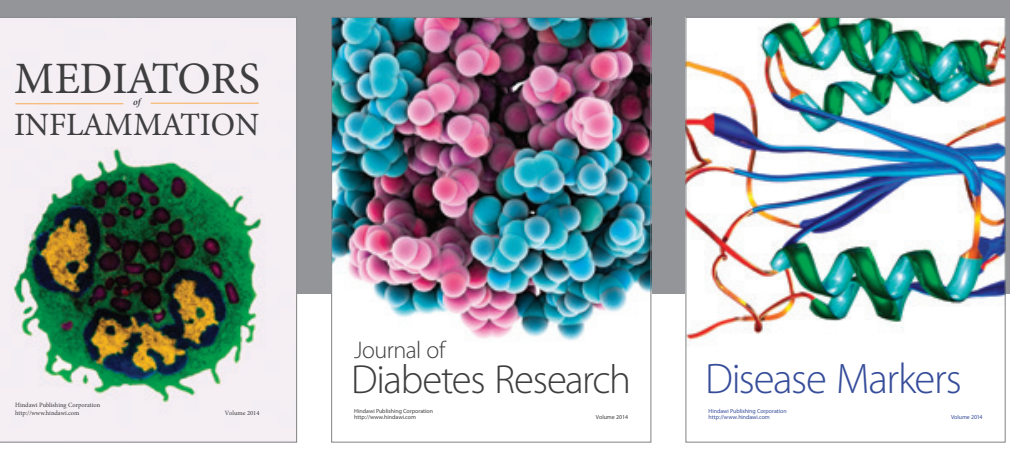

Disease Markers

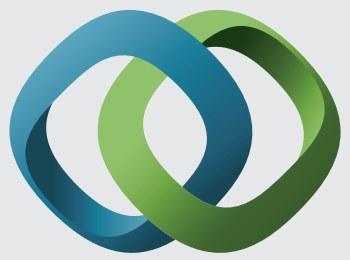

\section{Hindawi}

Submit your manuscripts at

https://www.hindawi.com
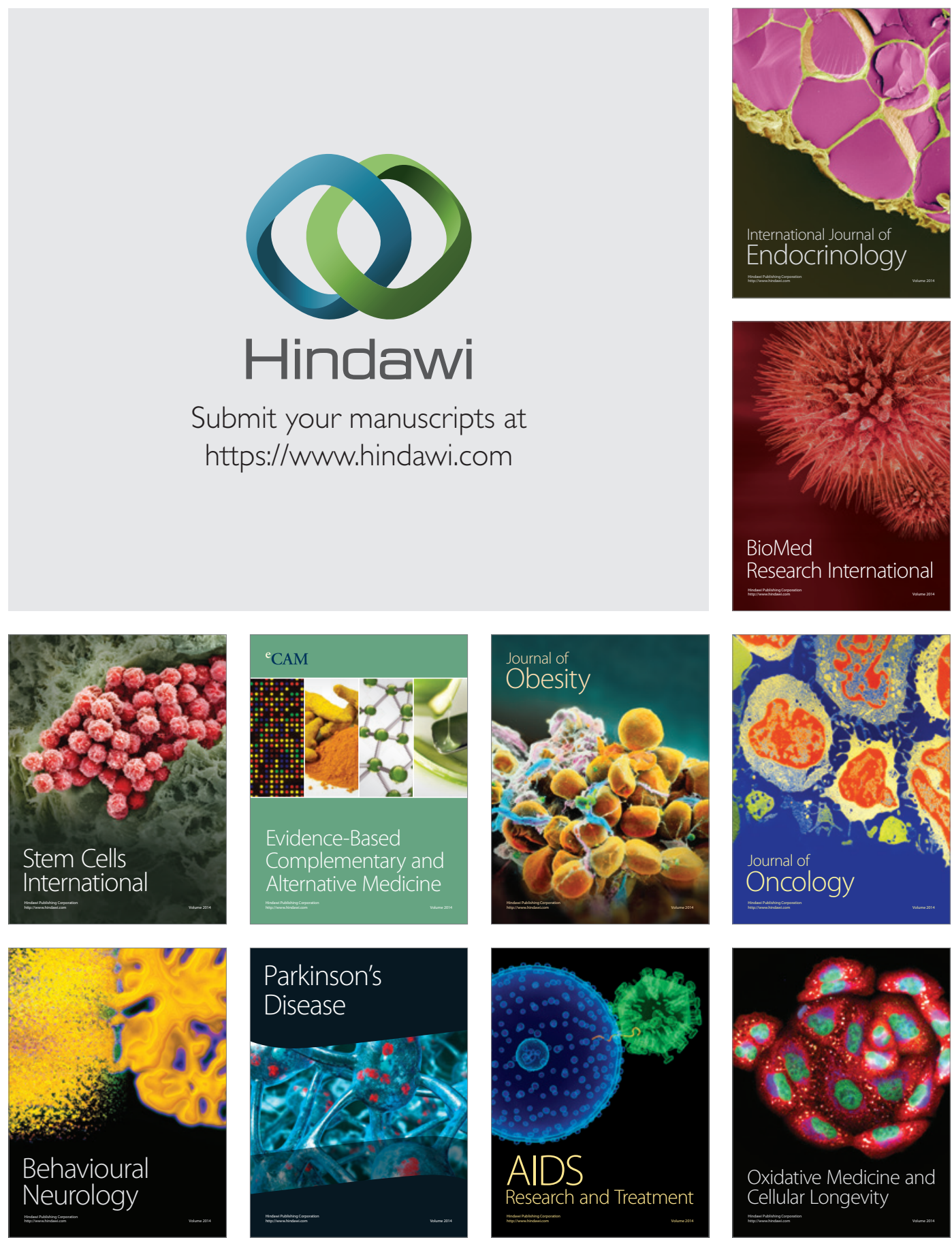